\title{
STIRNER - ON THE BRINK OF SCIENTIFIC THOUGHT
}

\author{
Beate Kramer \\ (Max Stirner Gesellschaft)
}

There is more between heaven and earth, Horatio Than has been dreamt of by your philosophy.

Hamlet, Shakespeare

When I listened to a lecture given by a physicist at a conference held by the German Philosophical Society, in Berlin, a few years ago, I was surprised to hear him answer an esoteric remark concerning the truth of physics by admitting that he himself "believed" in quantum mechanics. That gave me an idea which turned into a question. Is it actually possible to "believe" in science, of which quantum mechanics obviously is a part, or do we if we "believe" in it exchange science for religion, thereby robbing science, as well as ourselves, from sober reflection on the world around us and on how we tend to appreciate it?

In some respects concerning knowledge and belief we seem to resemble Douglas Adams's Electric Monk, who is very capable of believing anything for a very short time till fashion or his own spiritual straying leads him to believe the detrimental of what he believed in the first place.

Scientific fashions alter from time to time, once human behaviour was thought to be dependent on men's own free will, now it is thought to spring from their genes. Myths are born and die only to be resurrected at certain intervals, depending on what people allow themselves to believe in. Actually, this seems to be a very well working strategy as far as science is concerned. Unfortunately, there does not exist a master plan after which these cycles of beliefs are fashioned, and can be measured. So we are presented with the following problem: is that what we find out to be latest truth really latest truth or is it something that we should shove under destiny's couch? What is the ultimate ratio, for let us say, 
explaining our neighbour's strange behaviour or even better Descartes' Cogito or lets us find the Higg's particle?

Actually we do not know. Here our friend Socrates would laugh in his grave turning around saying "I told you so". But it is his sense of science we go by and we are doing it quite successfully, namely asking questions and being aware that each given answer leads to further questions. The questions might not be consistent, neither might be the answers. Natural science, when theology parted it from philosophy, went his way while philosophy went Plato's and tried to find not dogmas, but reason. Natural science, unaware of the problems both theology and philosophy wanted to saddle it with, happily plodded on and got very favourable results. We do not have to believe in them, though. This is where science and religion go different ways. As Stirner says, as Feyerabend says. Stimer says so in a more intuitive version, Feyerabend in a more sophisticated one. For Stirner we have to recur to some points he made in his main work The Ego and His Own, for Feyerabend we find all of his arguments in Against Method, Farewell to Reason and his philosophical papers on rationality.

But, why is it important to sustain dissent with the assumption that method is the one and only vital motor of scientific progress? The first answer is obvious, to prove that science is not religion, and furthermore that scientific processes do not run along the so-called rules of reason, that reason is the least to do with science. Secondly, believing in reason as a scientific principle proves to be religion in itself. Thirdly, we should think about which scientific fashions we should adhere to for our own good, see above mentioned couch of destiny.

Let me explain in a few sentences how the rather roundabout three answers can be validated by arguments - not all to reason. "Why is an axiomatic mathematical truth, which could be called an eternal one in the common sense understanding of eternal not a sacred one?" Stirner asks to answer this question by himself, because this axiom is not disclosed by a higher spirit. This is not a rhetorical answer.

Here we have the first hint as to how Stirner wanted science to be understood. Scientific truth obviously is not conferred to us by some kind of revelation, something given to us to be held on to truthfully forever, but something we develop for ourselves. But Stirner was not so naïve to hold, that individuals go on valid scientific research each for themselves.

"And as quantum theory is not a divine emanation but a human product, we shall have to study it in the form in which human products

\footnotetext{
${ }^{1}$ Stirner, Max, Der Einzige und sein Eigentum, p. 40; "Warum ist eine unumstößliche mathematische Wahrheit, die nach dem gewöhnlichen Wortverstande sogar eine ewige genannt werden könnte, keine - heilige?”
} 
usually are available" 2 . Feyerabend seemed to have been of the same opinion. Results of science or its laws are not revealed to us not even rationally to be sought out. "Science is not sacrosanct"3. Feyerabend and Stirner share the conviction of science being a construction of the human mind.

They equally voice the opinion that despite science itself producing inconsistencies as well as results its proceedings nonetheless follow a certain rationale. And furthermore they both claim that to codify a definite approach to phenomena or matter, i.e. to establish a definite method for taking a look into things, turns science into religion and scientists into believers.

Naturally it would be unfair to measure Stirner's knowledge in physics against Feyerabend's since in the meantime several years relapsed and our view of the world has been completely changed by what could righteously be called the relativistic or quark revolution. Stirner must have known at least some physics according to his biography, but physics he could have known was of the classical mechanics type. Feyerabend started to think after Planck invented his physical constant and Einstein discovered light as a tool to invent a completely new conception of time and space.

But the principles from which Stirner and Feyerabend derive their judgements, if they really can be denoted principles, can be compared even if they take different approaches. These principles stem from sources of the middle of the $19^{\text {th }}$ century. Stirner tries to think on his own, Feyerabend sometimes explicitly resorts to Kierkegaard ${ }^{4}$, a thinker he regards very well as one of his predecessors in revolutionary thinking. Both were motivated as Feyerabend put in his autobiography Killing Time: "to free people from the tyranny of philosophical obfuscators and abstract concepts such as "truth", "reality" or "objectivity" which narrow people's vision and ways of being in the world"5.

Let me now slightly rephrase Feyerabend's famous words: Is it possible for science to achieve results by strictly obeying the methodological approach prescribed to it by rationalists? "And to this question the answer seems to be a firm and resounding $\mathrm{NO}^{\prime}$.

${ }^{2}$ Feyerabend, Paul, Against Method, p. 190.

${ }^{3}$ Feyerabend, Paul, Against Method, p. 214.

${ }^{4}$ See Feyerabend, Paul, Against Method, p. 154. Kierkegaard is one Feyerabend's authors of reference when it comes to his anthropological approach towards changing scientific procedure.

${ }^{5}$ Feyerabend, Paul, Killing Time, p. 179.

${ }^{6}$ Feyerabend, Paul, Against Method, p. 154. 
In order to elucidate Feyerabend's remark as well as to probe whether it is possible to apply it to Stirner's approach towards science it is helpful to consider the above mentioned abstract concepts truth, reality and objectivity and see which role they play in either philosophy by substantiating the provisional answers already given to the above question. A second step will be taken to find out whether Stirner's theory of science can be placed somewhere between conventional dialectical thought and $20^{\text {th }}$ century approaches. To stress the differences between Feyerabendian and Stirnerian thought will conclude the argument.

\section{Truth, Reality, and Objectivity}

Stirner rarely explicitly refers to scientific truth, but more so to truth as an absolute concept which he deems must be utterly antagonized on various grounds. Truth on the whole is considered a chimera deriving from speculative thinking a scientific method despised by Stirner, because it lacks motility and operates on so called objective hypotheses. "In the most advanced stage of civilisation this activity earns the name of scientific activity, of working on a motionless presupposition, a hypothesis that is not to be upset"? Stirner diagnoses his age and his contemporaries as being hopelessly imprisoned in redefining instead of destroying speculative thinking.

Truth derived from sceptical analysis of reality following the Cartesian principle of the Cogito is also a misleading attempt insofar when parting res cogitans from res extensa solely the thinking thing remains extant ${ }^{8}$. On the whole Stirner's criticism aims at the two prevailing methods then accepted by philosophical thinkers, speculation and deduction, both methods turning those who seek truth into truth's slaves instead of independent thinkers.

But how then is truth to be attained at all when being truth's slave is dishonourable for the unique one. Furthermore, achieving truth is impossible because firstly it is transitory, secondly not revealed by a superior being nor thirdly can it be sought, which leaves it a concept to fool believers into believing.

${ }^{7}$ Stirner, Max, Der Einzige und sein Eigentum, S. 73; The Ego and His Own, p. 68, "Auf der vorgeschrittensten Bildungsstufe verdient diese Tätigkeit den Namen der wissenschaftlichen, des Arbeitens auf einer unbewegten Voraussetzung, einer unumstößlichen Hypothese"

${ }^{8}$ Stirner's reading of Descartes might be misleading though since Descartes did not establish existence of being by postulating I think - I am but simply was searching for an irrefutable principle to found scientific thought and research. 
The correspondence formula - adcequatio rei et intellectus implying that an object or a thought clearly and distinctly perceived as corresponding to reality is not Stirner's touchstone, at least not when dealing with ideas. Against the notion of ideas being true in a rationalist sense he consequently puts the notion of truth and ideas as creation. He reasons as follows. Truth is what the Unique owns, nothing he strives for, and if objects exist they can be appropriated, so can ideas be appropriated, if appropriated they can be observed and true statements can be delivered on objects as well as ideas. Otherwise truth becomes a completely meaningless term.

You address yourself to thoughts and notions, as you do the appearances of things, only for the purpose of making them palatable to you, enjoyable to you and your own. You want only to subdue them and become their owner, you want to orient yourself and feel at home in them, and you find them true, or them in their true light, when they no longer slip away from you, no longer have any unseized or uncomprehended place, or when they are right for you, when they are your property. ${ }^{9}$

Since the Unique is unspeakable, we might be tricked by Stirner into appreciating that truth also cannot be spoken, but I think this is not meant here. The Unique being unspeakable does not include him to be unknown, it just means no attributes can be attached to him from the outside; therefore he can neither be named nor subsumed under a general concept of humanity. That is all. But as long as the Unique can appropriate anything he can appropriate truth, therefore he is able to deliver true statements. Insofar he is able to communicate truth at least in the Union of the Uniques.

Stirner solely rejects the idealistic version of truth; he does not sincerely doubt that true statements can be made. The same he holds for the concept of reality, which when being of a non - speculative kind is not included in his line of attack, therefore his line of attack does not include natural science or existing objects. His attack also covers reason which in idealistic thought replaces Bacon's or Hume's philosophical

${ }^{9}$ Stirner, Max, Der Einzige und sein Eigentum, p. 397 - 398; The Ego and His Own, p. 353, "Du machst Dich an die Gedanken und Vorstellungen wie an die Erscheinungen der Dinge nur zu dem Zwecke, um sie Dir mundgerecht, genießbar und eigen zu machen, Du willst sie nur bewältigen und ihr Eigner werden, willst Dich in ihnen orientieren und zu Hause wissen, und befindest sie wahr oder siehst sie in ihrem wahren Lichte dann, wenn sie Dir nicht mehr entschlüpfen können, keine ungepackte oder unbegriffne Stelle mehr haben, oder wenn sie Dir recht, wenn sie Dein Eigentum sind". 
concepts of common sense or even overrules nature herself, thus turning philosophy from a method of learning to be aware of environment or nature to a purely religious form of belief ${ }^{10}$.

A concept of truth Stirner also rejects should not be confounded with the one dwelt upon above - namely the one at which heart lies the notion of transitory validity of ideas and theories. Today this concept of truth has become a truism and pundits are inclined to claim that our scientific progress allows for more and more knowledge, thus enabling us to gain more and more insight into matters material, achieving more and more the capability of making true statements on the nature of our surroundings. Some statements that have been held valid in the past lose their validity, hence become obsolete and are exchanged for more promising ones. Here Stirner observes the following fallacy: even if truth is deemed to be transitory instead of absolute - allowing for errors, misinterpretations of ideas - still the notion that truth is extant somewhere to be discovered, remains alive and well. Thus it can be suspected that when criticising concepts of truth and criticising the science that reveals it, Stirner had in mind truth in the Hegelian sense. Moreover, truth is not worthwhile a topic to probe since its existence cannot be guaranteed. This renders absolute truth as well as transitory truth a purely metaphysical objective to be believed in or not, possibly at will, whereas mathematical truth seems to be of a totally different quality. Three explanations are possible.

Stirner's idea of mathematical truth is detrimental to truth in any other sense he is discussing throughout his book. Mathematics is the paradigm of the kind of truth that can rightfully and completely be appropriated; it is of a common sense value; not revealed by a superior being; it cannot be arrived at by speculation. That leaves only one method, i.e. individuals can only achieve mathematical truth by using their understanding. Once they have obtained it, they can communicate it.

The first explanation the Platonic argument in favour of mathematics' eternal truth can easily be rebutted on the above grounds. Stirner repudiates metaphysics using non-metaphysical reasoning insofar he sends modern sciences of his time, namely mathematics and physics ${ }^{11}$, into the race against the rationalism of Hegelian origin. The concept of Platonic ideas would contradict the common sense attitude of Stirner's thinking, because in Plato's conception truth is lying behind appearances, a way of thinking Stirner thoroughly rejects.

10 See Stirner, Max, Der Einzige und sein Eigentum, pp. 93 - 94; The Ego and His Own, p. 86-87.

11 The background would be the then new development of positive sciences, e. g. research in electro - dynamics by Faraday and Volta or research in modern chemistry. 
The second explanation would be based on conceiving mathematics not as a form of science, but simply as a method for designing logic systems operational in various fields of scientific or other research. Despite that this view is widely accepted nowadays, Stirner does not adhere to it. To the contrary, it is unlikely that Stirner would support it, since it falls into the same category as transitority of truth in general, which he rejects as shown above.

The third is the most likely explanation. Stirner confronts absolute or any other not appropriated truth with his notion of mathematical truth decrying both kinds of concepts as non-scientific but beliefs, whereas mathematical truth is matter of fact truth. Truth is not to be had both ways.

If mathematics is factual it neither can be a scientific construct nor a metaphysical collection of ideas, but instead is a method for correctly describing what happens in the world around us or elsewhere. Here mathematics coincides with physics, a science just then in the process of being pushed forward by new discoveries. To sum up absolute truth is a metaphysical construct, mathematical truth as opposed to metaphysics is factual, insofar there are extant physical objects which can be correctly described and explained by mathematical methods. Not a metaphysical system based on one principle, but a common sense approach towards knowledge lies at the core of Stirner's deliberations on truth. Hence it does not follow that truth is as arbitrary a concept as is, e. g. certitude.

The question whether Stirner, when it comes to his concept of truth, belongs to Feyerabend's band of philosophical obfuscators cannot easily be answered. On the one hand the answer must be "No, he does not", because he vehemently disapproves of metaphysics on the whole, but on the other hand, since he fails to definitely explain what he understands as to be appropriating truth and lets us infer for ourselves, the answer "No" might have to be reconsidered and mistrust in his theory might be fuelled.

\section{The consistency principle}

The consistency principle serves as another touchstone for probing the leading question. Rationalism as well as empiricism demand theories to meet the consistency principle, which allows for theories neither to contain self-contradictory elements nor to be at odds with facts. "Cognition has its object in life" 12 Stirner claims. But what does Stirner include when he speaks of life, solely human existence or more than just that? If life is cognition's object, then surely this also includes objects and

12 Stirner, Max, Der Einzige und sein Eigentum, p. 94; The Ego and His Own, p. 86. "Am Leben hat das Erkennen seinen Gegenstand". 
processes around us. We can safely assume that since he deems statements made on these objects and processes to be only consistent, when firmly grasped by the Unique's knowledge, he partly would agree with Feyerabend's stance that "theories cannot be derived from facts"13.

Feyerabend's author of reference here is the philosopher David Hume, one of Stirner's most revered authors, if any. As Hume explains, facts are only observable in a disintegrated fashion, therefore processes cannot be observed at all. Observations of objects are integrated into the human mind by the human mind's using a connecting principle, mainly the principle of cause and effect. If Hume is taken seriously, it follows that we fashion theories according to processes in our minds rather according to processes in reality. A fact-fitting theory in the end is as obscure as a theory which is supported by no fact at all.

Therefore, the first step in our criticism of customary concepts and customary reactions is to step outside the circle and either to invent a new conceptual system, for example a new theory, that clashes with the most carefully established observational results and confounds the most plausible theoretical principles, or to import such a system from outside science, from religion, from mythology, from the ideas of incompetents, or the ramblings of madmen. This step is, again, counterinductive. Counterinduction is thus both a fact - science could not exist without it - and a much needed move in the game of science. ${ }^{14}$

Counterinduction, not to be confused with deduction, is the method Stirner employed to criticise Hegel and his ilk, the Young Hegelians from left to right, reducing their systems to near nothingness.

Therefore, if we can, according to Stirner, make at least some true statements derived from knowledge of objects, then we must point out that he at least partly is in disagreement with Feyerabend notions about science, since Stirner rejects obscure theories which cannot be substantiated by physical evidence. Insisting on the consistency of theory and fact surely at Stirner's times was deemed to be an appropriate scientific method even if fact and theory actually were at odds with each other as has been depicted by historians of science ${ }^{15}$.

${ }^{13}$ Feyerabend, Paul, Against Method, p. 50

${ }^{14}$ Feyerabend, Paul, Against Method, p. 52-53. To dwell upon this theorem to the extent it deserves requires more space than can be provided here; and it has already been done so extensively by Feyerabend himself, so it can be assumed that the reader is familiar with it.

15 See e.g., Thomas S. Kuhn in The Structure of Scientific Revolutions on scientific paradigms. 
But Feyerabend holds against this simple idea that the consistency principle does not allow for ad hoc hypotheses which are nonetheless very profitably used in scientific procedure, facts can be at odds with an otherwise perfect theory. Therefore a valid theory does not even need to be consistent in itself. Facts might not fit a theory or vice versa, but inconsequentially imperfect theories are kept due to hunches or suppositions, sometimes to good avail.

Prima facie Stirner's thinking seems to be in accord with Feyerabend's proposition.

All predicates of objects are my statements, my judgements, my creatures. If they want to tear themselves loose from me and be something for themselves, or actually overawe me, then I have nothing more pressing to do than to take them back into their nothing, into me the creator. ${ }^{16}$

But then he recurs to a very ancient principle "(Potentiality) possibility and (actuality) reality always coincide" ${ }^{17}$. Taken seriously the proclaimed identity of potentiality and actuality, further referred to as the identity principle, carries far - reaching consequences both in science and logic. Two distinct principal interpretations roughly to be categorised as transcendent and immanent lead to different consequences shedding light on the architecture of the interpretations themselves as well as their foundations, and naturally on the architecture of Stirner's theory.

\section{Theory Design}

The transcendent interpretation of the identity principle begins with Aristotle and leaves a conundrum which has been giving philosophers thought over centuries and cannot be decided once and for all. Potentiality, virtual power leaves room for contingency, i.e. not everything that is possible has to become actual. According to Aristotle potency and actuality are distinct features of life or existence ${ }^{18}$, potency

16 Stirner, Max, Der Einzige und sein Eigentum, p. 378; The Ego and His Own, p. 337.. "Alle Prädikate von den Gegenständen sind meine Aussagen, meine Urteile, meine - Geschöpfe. Wollen sie sich losreißen von Mir, und etwas für sich sein, oder gar mir imponieren, so habe ich nichts eiligeres zu tun, als sie in ihr Nichts, d.h., in Mich, den Schöpfer, zurückzunehmen".

${ }^{17}$ Stirner, Max, Der Einzige und sein Eigentum, p. 369; The Ego and His Own, p. 329. "Möglichkeit und Wirklichkeit fallen immer zusammen".

18 See Aristotle, Metaphysics. Whether Aristotle's assumptions which have been disputed throughout the centuries are false or true is of no concern to this paper. 
denoting the capacity of acts or of beings that have yet to come to be, actuality denoting beings or acts that have left the realm of potentiality to become actual.

This is a reading Stirner obviously does not favour. Potency is only to be had when an act actually is performed, otherwise the act could not have been performed in the first place. Being always is actuality and potentiality at the same time. He takes up Aristotle's example of the man who is only capable of standing when standing not otherwise, and reverses it. "One can do nothing that one does not, as one does nothing that one cannot" 19 . Aristotle thought this notion to be illogical. But for Stirner this notion fortunately leaves no room for a creator who must have, if he really is a creator, some virtual being up his sleeve as it were.

Creationism insisting on a benevolent and almighty deity has it that $\mathrm{he}^{20}$ ensures the existence of everything that is. Furthermore, depending on the particular religious denomination, everything that was created, is thought to be still ruled by a superior being. This is a theory obviously disclaimed by Stirner.

By insisting on the identity principle, Stirner also excludes the philosopher's god from his theory, "a god with grander things to do than fuss about human distress. Or a god who is not indifferent to suffering but regards it as the price that has to be paid for free will in an orderly, lawful cosmos"21. This god of deism is not a wilful or benevolent supernatural intelligence, but god becomes a principle designated for explaining being and change.

The immanent interpretation of the identity principle as offered by Spinoza proposes that no deity could have arranged the world differently from the way he did. "Things could not have been brought into being by God in any manner or in any order different from that which has in fact obtained"22. In Spinoza's reading of the identity principle there is no difference between potency and actuality since the laws of nature rule supreme, whether our cognitive abilities allow us to discern nature's rule wholly, partly, or not at all. Naturally, this implies that single things can perish or appear according to natural law, change is allowed for, but the

19 Stirner, Max, Der Einzige und sein Eigentum, p. 369; The Ego and His Own, p. 329. "Man kann nichts, was man nicht tut, wie man nichts tut, was man nicht kann".

20 God may as well be a black female.

${ }^{21}$ Dawkins, Richard, The God Delusion, p. 135.

22 Spinoza, Baruch de, Ethica I, propositio XXXIII and scholium II. "Res nullio alio modo, neque alio ordine a Deo produci potuerunt, quam productae sunt". "Die Dinge konnten auf keine andere Weise und in keiner anderen Ordnung von Gott hervorgebracht werden, als sie hervorgebracht worden sind"..Translated from the Latin by R.H.M. Elwes (1883); source: users.erols.com/nbeach/spinoza.html 
laws as such never change. Whether Stirner would intentionally agree with Spinoza or not is of little importance, instead it is of vital importance to ascertain whether their concepts match.

A supremely ruling law of nature seems to be as undisputed among scientists in the antique world as it is today, despite the fact that we neither do know if we recognise it correctly or totally misread it, nor do we know reliable methods for how to achieve correct knowledge of its rules $^{23}$. But independently from our understanding of what is going on inside and outside ourselves, something is going on following a rule. If this supposition is correct, then everything that is, actually is. Moreover, if laws of nature do not change, then everything they generate does exist ${ }^{24}$. It would be ridiculous to assume nature would hold anything back in order to irritate or frustrate our understanding, or simply be playing nasty jokes on us. The so-called butterfly effect is no exception of this infallible rule.

If we can safely assume that Stirner's thoughts run along these lines, we then can draw a very provocative conclusion: Not only does he criticise the Young Hegelians with respect to the content of their theories, he is also undermining their mindset which is set on revamping the original theory for further use in fields originally not included in Hegel's system $^{25}$. To support this conclusion we should be probing the logical design of his theory. In order to do so the change of his mindset are to be placed at the centre of the probe. His earlier essays rebut his contemporaries, but Stirner is still thinking in dialectic terms as can be shown by a very fine example from one of his early essays in which he writes the following paragraph:

Only philosophers can die and dying find their proper self; with their death the age of reformation, the age of knowledge, dies. Yes, so it is, knowledge itself must die, to again blossom in death as volition; [...] $\mathrm{He}$, who henceforth wills to preserve knowledge, will lose it, but he, who relinquishes it, will gain it. Solely philosophers are summoned to relinquishing and gaining: it is they, who stand before the flaming fire and must need, like the dying hero, burn their earthly shell, if the imperishable spirit is to be set free. ${ }^{26}$

${ }^{23}$ I am thinking of the major scientists as Archimedes, Erathosthenes, Serapion of Alexandria, and the like, not necessarily of Plato.

24 The great Heraclites seemed to have had a faint idea of this when uttering his

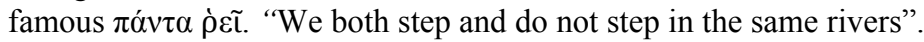

25 Probably Stirner thought of physics, he must have even had a good and probably even better grasp than Marx on economy, Stirnerians could contribute to an opening discussion.

26 Stirner, Max, Das unwahre Prinzip unserer Erziehung, oder: Humanismus und 
Dying to just rise as phoenix from the ashes is a classical rhetorical device, simply saying what has been sacrificed will be regained in the same form. Knowledge dying to just rise is Stirner's specification of this device, but added to with a logical twist. It is not to rise as a new form of knowledge, but as a third, as volition. The second part of the quote seems to thwart the first part since here knowledge is our simple phoenix. But it is not so. The phoenix rising from the burnt knowledge is the spirit. Stirner here precariously designs a dialectic equation, volition equals spirit $^{27}$.

Basically this way of thinking is derived from the logic Hegel developed when he construed the drive he thought to be intrinsic to the law of non-contradiction, the same statement cannot be true and false simultaneously. Hegel's version of the law of non-contradiction claims proposition and negation necessarily form a contradictory unit which powerfully moves the world's development.

But it is one of the fundamental prejudices of logic as hitherto understood and of ordinary thinking that contradiction is not so characteristically essential and immanent a determination as identity; but in fact, if it were a question of grading the two determinations and they had to be kept separate, then contradiction would have to be taken as the profounder determination and more characteristic of essence. For as against contradiction, identity is merely the determination of the simple immediate, of dead being; but contradiction is the root of all movement and vitality; it is only in so far as something has a contradiction within it that it moves, has an urge and activity. ${ }^{28}$

Realismus, p. 85 - 86. "Nur die Philosophen können sterben und finden im Tode ihr eigentliches Selbst; mit ihnen stirbt die Reformations-Periode, das Zeitalter des Wissens. Ja, so ist es, das Wissen selbst muss sterben, um im Tode wieder aufzublühen als Wille; [...] Wer hinfort das Wissen bewahren will, der wird es verlieren; wer es aber aufgibt, der wird es gewinnen. Die Philosophen allein sind berufen zu diesem Aufgeben und diesem Gewinn: sie stehen vor dem flammenden Feuer und müssen, wie der sterbende Heros, ihre irdische Hülle verbrennen, wenn der unvergängliche Geist frei werden soll".

27 This does go further than Hegel ever went and reminds of Schopenhauer's idea of volition and imagination ruling supreme.

${ }^{28}$ Hegel, Georg Friedrich Wilhelm, Logik I, 2. Buch, 1. Abschnitt, 2. Kap., C. Der Widerspruch, Anmerkung 3, § 956. "Es ist aber eines der Grundvorurteile der bisherigen Logik, und des gewöhnlichen Vorstellens, als ob der Widerspruch nicht eine so wesenhafte und immanente Bestimmung sei, als die Identität ${ }^{28}$; ja wenn von Rangordnung die Rede, und beide Bestimmungen als getrennte festzuhalten wären, so wäre der Widerspruch für das Tiefere und Wesenhaftere zu nehmen. Denn die 
Contradiction, so Hegel's assumption, is at the root of life itself, the driving force of everything alive and well. There must always be some contradiction be swirling around, otherwise life would cease to exist; such would be the conclusion if this hypothesis was thought through to its end. Everything that exists, owes its existence to things that developed due to their intrinsic contradiction and will bring forth anything by unfolding their own intrinsic contradiction. This thought alone is hard to swallow, but what is totally submerged here is, that contradiction just means $\mathrm{p} \wedge \neg \mathrm{p} ; \neg \mathrm{p}$ being the negation of the proposition $\mathrm{p}$.

Contrary to Hegel's view on logic, Trendelenburg's ${ }^{29}$ view negates the moving power of the innate contradiction. To the contrary, contradiction coerces the mind to distinguish between concepts of logical as well as metaphysical origin in order not to confuse matters, i.e. to keep them apart.

When contradiction inexorably keeps apart thoughts one wishes to put together, when it disunites thoughts which believed to be united and renders uncertain the certain: one senses the power of thought behind the power of the contradiction simultaneously with the inherent necessity which is giving laws to thinking. One senses on the bottom of the contradiction the necessity which is the enigma common to logic and metaphysics. ${ }^{30}$

Further on, Trendelenburg words his concept of negation: "Non A is everything that is not $A$ "31. This is the principle of distinction. A structural synthesis of thesis and anti-thesis is a logical paradox if thesis and anti-thesis are viewed as forming a contradiction and not as just

Identität ihm gegenüber ist nur die Bestimmung des einfachen Unmittelbaren, des toten Seins; er aber ist die Wurzel aller Lebendigkeit; nur insofern etwas in sich selbst einen Widerspruch hat, bewegt es sich, hat Trieb und Tätigkeit”.

${ }^{29}$ Members of the examination board before which Stirner took his exams as a young man were the famous Kantian and critic of Hegelian logic the logician Alfred Trendelenburg, who held the chair of philosophy at Berlin University, and the classicist Meinecke.

${ }^{30}$ Trendelenburg, Friedrich Adolf, Logische Untersuchungen, S. 11. "Wenn der Widerspruch Gedanken, die man zusammenbringen möchte, unerbittlich auseinander hält, wenn er Gedanken, welche sich einig glaubten, entzweiet und das Sichere unsicher macht: so fühlt man hinter der Gewalt des Widerspruchs die Macht des Denkens und zugleich den Zwang der Sache, welche dem Denken Gesetze gibt. Man empfindet im Grunde des Widerspruchs die Nothwendigkeit, welche das gemeinsame Rätsel der Logik und Metaphysik ist".

${ }^{31}$ Trendelenburg, Friedrich Adolf, Logische Untersuchungen, S. 169. "Nicht-A ist alles was nicht $\mathrm{A}$ ist". 
contrasting each other. Contrastive concepts are high and low, but the negation of low is not high, but non-low.

From these different logical approaches - whereby neither Hegel nor Trendelenburg are the first ones having thought of them - stem two distinctive kinds of theoretical approaches towards explaining what is inside and outside us, in which the identity of potentiality and actuality are accentuated very differently. While the dialectic mode takes a teleological approach, the non-dialectic mode takes an ateleological approach.

Now, a contradiction in the Hegelian sense contains an urge towards development, a new state is reached when the contradiction is driven by its dialectic forces to disjoint into proposition and negation which then sublate to attain a new quality, eternally spiralling off the same such process by which further development is determined. Possibilities not yet extant will then unfold. The contradiction would be responsible for any development, the end of which however, would remain rather elusive, if there was not an inbuilt $\tau \varepsilon \lambda \circ \zeta$ in the whole process. But what the $\tau \varepsilon \lambda \circ \zeta$ could be remains equally elusive and has kept changing throughout the centuries from Plato's eternal Good, to the perfectibility of mankind, to Hegel's Prussian state, or the communist ideal of an egalitarian society. Stirner's efforts in his main work strive at showing exactly this flaw in the dialectic mode of thinking.

All that is is, potentiality equals actuality, are sentences that cannot be derived from dialectic logic. If dialectic logic was applied to the laws of nature, things would become truly weird indeed; universal validity of the dialectic mode would require laws of nature to perpetually develop by disuniting and synthesizing in order to unfold themselves, which would at best render us a bunch of hapless ignorami, or at worst not to have come into existence at all.

But, seen from a different point of view, Stirner's statement on the phoenix rising from the ashes does make sense, laws of nature whether known to us or not can be stated, and it is then up to us to appropriate the provided knowledge, or not. Even if we consider Darwinian evolution, which theory Stirner could not have been familiar with, it runs along those laws of nature, despite the fact that, in Stirner's times, most people still were of the opinion that a deity created the world a few thousand years ago, a belief that was soon to be shattered. Whether human beings actually did evolve as postulated by Darwin is absolutely irrelevant, it is also irrelevant if the laws postulated are consistent, or not.

To sum up, Stirner's approach to gain knowledge of the world is more consistent with the scientific approaches of his time than consistent with the approach derived from dialectic logic, an approach which could not satisfy his contemporaries, who in general adopted the Hegelian line 
of thinking instead. Stirner was one of the very few philosophers in the 19th century who thought in terms of science - mind, not Hegelian science - and science was to him the motor of knowledge of the world.

\section{Marx's / Engel's Criticism}

Marx and Engels especially fell out with Stirner's approach very early, branding him as a useless to dangerous individual. Taking what he writes as its face value, totally missing the irony, they resolve to show that Stirner wrongly applies the dialectic mode, furthermore that he seems not to have understood it, equally missing the point. They go great length to demonstrate that Stirner is unable neither to correctly deliver an account of the historical process that lead to society's then shape nor to apply the dialectic method correctly ${ }^{32}$.

Engels / Marx think along the Hegelian terms of philosophy of history not in terms of logic or natural science, so they commit the post-hoc fallacy to place natural and historical processes under the same dialectic law as if a quasi law of nature directs history teleologically towards a definite point of sublation, from which the whole process derives the new energy needed to begin again on a higher level.

In reality, of course, what happened was that people won freedom for themselves each time to the extent that was dictated and permitted not by their ideal of man, but by the existing productive forces. [...] Thus, society has hitherto always developed within the framework of a contradiction - in antiquity the contradiction between free men and slaves, in the Middle Ages that between nobility and serfs, in modern times that between the bourgeoisie and the proletariat. ${ }^{33}$

Stirner's sole crime was to ask why and how. Well, but for to be judged as having proceeded scientifically Marx and Engels should have considered to probe their ideas empirically; Stirner tries at least if not to

32 See e. g. Engels, Friedrich / Marx, Karl, Deutsche Ideologie, pp. 322ff. on the topic of crime and punishment or pp.332-334 on property and state; WWW.MARXISTS.ORG/ARCHIVE/MARX/WORKS/1845/GERMAN-IDEOLOGY

${ }^{33}$ Engels, Friedrich / Marx, Karl, Deutsche Ideologie, p. 417, WWW.MARXISTS. ORG/ARCHIVE/MARX/WORKS/1845/GERMAN-IDEOLOGY, "In der Wirklichkeit trug sich die Sache natürlich so zu, dass die Menschen sich jedesmal so weit befreiten, als nicht ihr Ideal vom Menschen, sondern die existierenden Produktivkräfte ihnen vorschrieben und erlaubten. [...] So hat sich die Gesellschaft bisher immer innerhalb eines Gegensatzes entwickelt, der bei den Alten der Gegensatz von Freien und Sklaven, im Mittelalter der vom Adel und Leibeignen, in der neueren Zeit der von Bourgeoisie und Proletariat ist". 
prove his statements, but to reject pure conjecture as a method which cannot be taken seriously. Because there is no way to find evidence for spirit, tasks, etc. being historic necessities he disavows any connection with these concepts. This is at least honest procedure.

Dishonest discourse verging on the brink of religious prejudice does not take into account that the favoured way of thinking might produce undesirable if not false results. A fine example of confusing natural with historical processes is given by Marx and Engels in which they demand using Hegelian logic that "the transformation of the individual relationship into its opposite, a purely material relationship, ... is a historical process" 34 . To offer the full benefit of what kind of thought Stirner is criticising Marx and Engels's are here quoted in full.

In the present epoch, the domination of material relations over individuals, and the suppression of individuality by fortuitous circumstances, has assumed its sharpest and most universal form, thereby setting existing individuals a very definite task. It has set them the task of replacing the domination of circumstances and of chance over individuals by the domination of individuals over chance and circumstances. [...] it has on the contrary called for liberation from a quite definite mode of development. This task, dictated by present-day relations, coincides with the task of organising society in a communist way. ${ }^{35}$

Despite that a communist society might be a good society to live in, a thesis strongly dubitable to Stirner ${ }^{36}$, there is neither any physical evidence nor is there any logical demonstration as to how and why the sudden change of quality might have come to pass in the course of history at any given time or in any given place.

${ }^{34}$ Engels, Friedrich / Marx, Karl, Deutsche Ideologie, p. 423, “das Umschlagen des individuellen Verhaltens in sein Gegenteil, ein bloß sachliches Verhalten is a geschichtlicher Prozess".

35 Engels, Friedrich / Marx, Karl, Deutsche Ideologie, p. 424, "In der gegenwärtigen Epoche hat die Herrschaft der sachlichen Verhältnisse über die Individuen, die Erdrückung der Individualität durch die Zufälligkeit, ihre schärfste und universellste Form erhalten und damit den existierenden Individuen eine ganz bestimmte Aufgabe gestellt. Sie hat ihnen die Aufgabe gestellt, an die Stelle der Herrschaft der Verhältnisse und der Zufälligkeit über die Individuen die Herrschaft der Individuen über die Zufälligkeit und die Verhältnisse zu setzen. [...], sie hat vielmehr die Befreiung von einer bestimmten Weise der Entwicklung vorgeschrieben. Diese durch die gegenwärtigen Verhältnisse vorgeschriebene Aufgabe fällt zusammen mit der Aufgabe, die Gesellschaft kommunistisch zu organisieren".

36 Stirner must have had a good and probably even better grasp than Marx on economy, Stirnerians could contribute to an opening discussion. 


\section{Positivism and Critico-Rationalism}

Stirner's thought might have been influenced by the positive sciences which have been extensively promoted to viable success during the $19^{\text {th }}$ century, but still his theory design does not comply with pure and simple positivism. According to Feyerabend a positivist is a researcher or philosopher who holds that scientific theories and other general assumptions are nothing but convenient means for the systematization of the data of our experience and that he is thereby committed to the view ... that interpretations ... do not depend upon the status of our theoretical knowledge ${ }^{37}$. Consequently, to a positivistic mind observation-based research does not depend upon theoretical hypotheses as to how to read observed data. A neutral observational language is supposed to guarantee the theory-free collection of any data on which then hypotheses are built in a second step. Carnap claims that this language only can be the language of physics.

It is rightfully demanded of science not to just bear subjective meaning, but to be meaningful as well as valid for all the various subjects participating in it. Science is the system of intersubjectively valid sentences. If we are right in our view that the language of physics is the only intersubjective language it follows that the language of physics is the language of science ${ }^{38}$.

Therefore, in an empiricist reconstruction of scientific knowledge objects are intersubjectively accessible, they are the primary objects of concepts. True statements can be made on all objects accordingly. Hence no preceding concepts are needed, preceding hypotheses on object behaviour are superfluous as well as a language construing these concepts $^{39}$.

${ }^{37}$ Feyerabend, Paul, Philosophical Papers, p. 20.

${ }^{38}$ Carnap, Rudolf, Die physikalische Sprache als Universalsprache der Wissenschaft, S. 333. "Von der Wissenschaft verlangt man mit Recht, daß sie nicht nur subjektive Bedeutung hat, sondern für die verschiedenen Subjekte, die an ihr teilhaben, sinnvoll und gültig ist. Die Wissenschaft ist das System der intersubjektiv gültigen Sätze. Besteht unsere Auffassung zu Recht, daß die physikalische Sprache die einzige intersubjektive Sprache ist, so folgt daraus, daß die physikalische Sprache die Sprache der Wissenschaft ist".

${ }^{39}$ I tend to regard every theory which pretends to operate purely empirically to be metaphysics in disguise, because it chooses to ignore its underlying premises when collecting data or information. If it does not ignore them, but conceals them it is intellectual fraud. Everything depends on unscrambling which tradition of premises produces which data. Then there remains another problem. There are no criteria to allow sorting any gathered field data. 
Natural sciences describe the space - time system we call nature based on observations and experiments. By concatenation of singular descriptive statements general terms are assembled the so called "laws of nature" ("induction"). From these derives the possibility to deduce new singular statements, e. g. forecasts ("deduction"). ${ }^{40}$

Appropriating knowledge, having the world and life itself as one's objects of enquiry, and rejecting fundamental principles as guidelines of research does sound like the Stirnerian refutation of metaphysics.

Making use of a purely observational language in order to probe experiences of all kinds instead of deriving a hypothetical language to build theories, from which then statements are deduced, seems to fit with Stirner's concluding formula Ich hab' mein Sach auf Nichts gestellt. Collecting data likewise unimpeded by deduction also seems to fit with this formula, which basically comprises his approach in a nutshell. To place the nucleus of a theory on "nothing" leaves space for a completely new approach towards cognition. Every step then taken towards it, is treading unknown grounds. Therefore a new language has to be developed before any observation can be noted or any hypotheses can be made from an observation.

Considering this together with the argumentation in Stirner's works a prima facie conclusion might lead to the result that this is exactly how he wishes science to proceed, but on second thought this conclusion becomes dingy. Stirner is neither a pure empiricist nor a pure positivist. His two hidden premises must not be forgotten, because they clearly demonstrate that he is neither, and that he actually does not place his initial point towards appropriating knowledge on "nothing". As a reminder, the first premise is: mathematics provides truth outside time and space, and the second one subsequently is: true statements can be made on objects and thoughts.

There might be a further reason for Stirner to so boldly close his The Ego and his Own, which should be at least mentioned before going on to the more conclusive ones. Having gone such length to destroy any persuasions and beliefs he encountered on his way towards his destination he may have well reached his theoretical point of no return and had to halt in midair, as it were, not finishing the thought experiment.

${ }^{40}$ Carnap, Rudolf, Die physikalische Sprache als Universalsprache der Wissenschaft, S. 317. "Die Naturwissenschaften beschreiben auf Grund von Beobachtungen und Experimenten die raum-zeitlichen Vorgänge des Systems, das wir Natur nennen. In Anknüpfung an die beschreibenden Einzelsätze werden dann allgemeine Formeln, die sog. "Naturgesetze" aufgestellt ("Induktion"). Diese geben die Möglichkeit, neue Einzelsätze, z.B. Voraussagen, abzuleiten ("Deduktion”)". 
There must be something said for his concluding formula, though. The salto mortale from empiricism of Humean provenience back to dialectical idealism was not possible anymore in his time. On the one hand, science was too advanced, as every one of his contemporaries could have known had they cared to inform themselves properly, on the other, a new theoretical approach alongside the development of science had not yet been in sight. Thus Stirner was one of the first thinkers of the $19^{\text {th }}$ century, at least in Germany, to embrace science and to totally reject unscientific thinking.

Nevertheless, there are still his two main premises to be considered if Stirner's thoughts are to be aligned with those of other philosophical or scientific approaches. The first premise is, mathematics is the foundation of truth, and the second one is that true statements can be made on experienceable objects. Assumed is, that objects behave according to natural laws not vice versa, that we describe object's behaviours, and name these behaviours laws. These premises contradict Stirner's concluding formula in its core. If mathematical truth sets the standard for truth in general then true sentences must be enunciated according to those logical rules mathematics implies. If truth is to be gained by observing mathematical rules in the process of research or thinking, then a clear methodological approach is prescribed to the researcher or thinker he has to follow regardless to what kind of objects or cognition he is probing.

But the assumption that truth can be found by employing a rationale does not comply with the idea that truth can be obtained by gathering and storing information of any kind in order to find a pattern from which a true thesis can be formed. Having a rationale, however hidden, might connect Stirner's way of thinking more closely to the approach towards knowledge and cognition later to be more explicitly and elaborately developed by Popper than to the positivism of the Vienna Circle.

To justify placing Stirner in the vicinity of Popper one aspect of both of their theories is of vital importance, namely the demarcation line Popper's criterion for parting empirical science from metaphysics and vice versa ${ }^{41}$. "The problem of finding a criterion which would enable us to distinguish between the empirical sciences on the one hand, and the mathematics and logic as well as 'metaphysical' systems on the other, I call the problem of demarcation" 42 .

Here we might also find another reason why Stirner did not go further and halted in midair. He happened upon Hume's induction problem that theories cannot be derived from facts ${ }^{43}$ - also posed by

${ }^{41}$ Popper, Karl, The Logic of Scientific Discovery, p. 10ff.

42 Popper, Karl, The Logic of Scientific Discovery, p. 11.

43 See Hume, David, A Treatise of Human Nature. 
Kant ${ }^{44}$ - Stirner found Hume's idea to be plausible and tried to solve the problem on his own account by first destroying the metaphysical ground to make way for a try on how to discern belief from knowledge, i. e. in his work he poses the demarcation problem to his contemporaries in a slightly different way, namely with respect to social and political theories in their own frame of mind not in terms of natural science.

His halting in midair though is due to his consequently being unable to offer a criterion to discern between metaphysics and empirical sciences, because a distinctive line could not have been conceived of, just sensed, like Stirner did when criticising contemporary Hegelian kind of science as operating with fixed and not to be upturned hypotheses. Marxism / Hegelianism as well cannot be conceived without such a hypothesis functioning as a metaphysical "nail in the wall" on which to suspend a system that allows for prediction and forecasts, claiming universal validity. These theories are working as already mentioned above with an immovable assumption, Stirner's unumstößlicher Hypothese, which is deemed to be able to reveal itself as true in the course of history, which history, so the fallacy, will develop accordingly.

To Popper's mind there is "no such thing as induction. Theories are, therefore, never empirically verifiable" 45 . Gaining knowledge of life and the world around us requires a different maxim to go by, namely that there are no immovable hypotheses at all, that hypotheses have to be upturned by inventing either new hypotheses or by simply experiencing their being invalid. Here we do find Stirner aligned with Popper's idea of a demarcation line. Even if Stirner did not proceed any further than destruction, there are some clues in the EGO AND HIS OWN that allow for interpretation.

As a rule experiments are conducted methodically. If we may try and reconstruct a scenario for conducting experiments from what we know of Stirner's attempts at a theory of science, we will come up with the following ingredients for such a scenario. Firstly, there are objects, life itself and the world around us, i. e. the physical world in general, secondly, there is the notion that fixed hypotheses about the content or the structure of these physical objects neither exist nor can be set up, thirdly experimental logic and mathematics allow for a method with which true statements on these objects and hypotheses about these objects can be distinguished from false ones. This means that statements on objects can be put to experimental tests and by their results can be corroborated or refuted in an infinite process for which a concept of final truth is not needed at all.

${ }^{44}$ See analytical and synthetical judgements in Kant, Immanuel, Kritik der reinen Vernunft, p. 52ff.

${ }^{45}$ Popper, Karl, The Logic of Scientific Discovery, p. 18. 
Naturally hence follows that "not the verifiability of a system but the falsifiability of a system is to be taken as a criterion of demarcation. [...] it must be possible for an empirical scientific system to be refuted by experience" 46 . A system of statements on objects which cannot be put to experimental tests does not meet the requirements of falsifiability Popper's touchstone of setting the demarcation line between metaphysics und empirical science. "We say that a theory is falsified only if we have accepted basic statements which contradict it. ... We shall take it as falsified only if we discover a reproducible effect which refutes the theory" ${ }^{47}$. An empirical system can be run through the experimental process of falsification to prove it to be non-metaphysical. The beauty of metaphysical systems is that they are based upon a rationale or a fundamental principle which might have been come by thinking or intuition, and the consistency principle is the only means by which these systems can be logically declared true or false. They might correspond with what is named reality or they might not.

\section{Feyerabend and Stirner}

Both thinkers, Feyerabend and Stirner, seem to have had a similar background from which they took off at a seemingly arbitrary tangent. Stirner took off from metaphysics, Feyerabend took off from critico-rationalism. They mainly differ in their concepts of reality. In Stirner's theory reality just is, therefore we might call his theory naïve, but in the best sense. But his theory is not that naïve that it claims that reality can be determined by mere observation. Feyerabend might hold with Popper's idea that "we shall guard against ... attaining for any chosen ... system what is called its "correspondence with reality""48. Starting with this idea, reality not just is, but becomes something murky and we fare much better if we regard ourselves as master builders of what we call reality.

For both applies what Jean Paulhan - a French publicist and editor wrote with respect to Kierkegaard.

Hardly had Fichte, Schelling, and the greatest of all three, Hegel, finished the majestic spirals and avenues of their systems, each of them felt disappointed. Everything was explained, there seemed to be nothing left worthwhile of being explained. From now on the smallest cog in the weltganze (mechanics of the world) had its place and rôle. Only everyone had lost the desire to set it in motion. It was like in a

\footnotetext{
46 Popper, Karl, The Logic of Scientific Discovery, p. 18.

47 Popper, Karl, The Logic of Scientific Discovery, p. 66.

48 Popper, Karl, The Logic of Scientific Discovery, p. 61.
} 
family in which the father uttered the apt word, made the final judgement: the children soon sense that he hinders everyone to think for themselves. They wonder: "But what is it to do with me?" In short, thinking had to begin anew. ${ }^{49}$

Stirner was initiated towards attaining a more scientific approach by the non-provable concepts he was presented with by his contemporaries, ending up as a proto-critico-rationalist in the broadest sense, and Feyerabend was initiated by just the same critico-rationalism and ended up with his formula of anything goes ${ }^{50}$. Stirner's approach towards science seems to be as anarchic as Feyerabend's, but it is not. We should not be deceived by Stirner's sometimes rambling and aggressive rejection of the would be scientific culture surrounding him. His anarchic ramblings prove him an eminent example for Feyerabend's claim of anything goes.

But with respect to science Stirner is no anarchist at all. To the contrary, he is not only morally rigid when it comes to knowledge, but is also strongly in favour of science to be marching forward in an orderly fashion, which simply does not comply with the fashionable order of science his contemporaries choose to pursue. Feyerabend being somewhat of the same mind as Stirner but having realised that science does not march on in an orderly way as preferred by philosophers of science and some scientists as well acquires a truly anarchic stance. From his investigation into the proceedings of science he concludes,

it has emerged that science is full of lacunae and contradictions, that ignorance, pigheadedness, reliance on prejudges, lying, far from impending the forward march of knowledge may actually aid it and that the traditional virtues of precision, consistency, 'honesty', respect for facts, maximum knowledge under given circumstances, if practised with determination, may bring it to a standstill. ${ }^{51}$

${ }^{49}$ Paulhan, Jean, Unter den Brücken der Metaphysik, S. 9-10. "Kaum hatten Fichte, Schelling und der größte der drei, Hegel, die majestätischen Spiralen und Alleen ihrer Systeme zu Ende gebracht, da empfand jeder von ihnen Enttäuschung. Alles war erklärt, es schien nichts mehr zu geben, das zu erklären sich lohnte. Das kleinste Rad des Weltganzen hatte von jetzt an seinen Platz und seine Rolle. Bloß hatte man die Lust verloren, es in Gang zu setzen. Es war wie in einer Familie, wo der Vater bei jeder Gelegenheit das treffende Wort, das abschließende Urteil spricht: die Kinder merken schon bald, daß er alle daran hindert, selber nachzudenken. Sie fragen sich: ,Aber was habe ich eigentlich damit zu tun?' Kurzum, das Denken mußte wieder von vorn beginnen".

50 Anything goes is not to be confused with "anything is true". Feyerabend is just saying that there is no single method that can be deemed to be inherently scientific nor to bring the desired results once employed.

${ }^{51}$ Feyerabend, Paul, Against Method, p. 197 
Whereas Stirner tries to put some sense of scientific method into people's minds and behaviour to make them pursue science for their own good $^{52}$, Feyerabend concludes that even the most utter nonsense might advance knowledge and cognition, because new ideas are at first dimly conceived and as dimly expressed. "So the inventor of a new world-view ... must be able to talk nonsense until the amount of nonsense created by him and his friends is big enough to give sense to all its parts" 53 , which is not to say that all utter nonsense is going to become scientific progress, it is just to say that during the process of inventing it cannot be decided whether the nonsense is going to be science, or whether it will remain nonsense. Feyerabend, as it were, takes the anthropological low road, whereas Stirner takes the scientific highroad towards knowing more about world and life.

Despite these differences there are similarities, though, beside the one that they both take off at a tangent of the periphery of theoretical systems. They both promote free access to science and knowledge; they both want everyone to have the chance to partake in scientific processes and progress - whatever these may be. Furthermost they want science, scientists, and last but not least philosophers of science, to be open-minded and be free to take any course without restriction or self-restriction. In this sense they are both truly - democratic.

\section{Concluding Remarks}

This essay has not been written to establish whichever philosophy of science produces the best or right results. It has neither been written to favour one of the above investigated theories over the others. It does not wish to qualify if metaphysics or if empiricism is the adequate approach, this is not its primary issue. Nonetheless it remains dubitable that metaphysics in its guise as mathematics really is unable to contribute to scientific research. Naturally, Stirner and Feyerabend would agree that it surely can and does. Its issue is rather to place Stirner in a row of thinkers, who depart from conventional philosophy.

If a demarcation line is to be made out it does not distinctly separate metaphysics from empirical science but separates a non-system-oriented approach from a system-oriented approach, and Stirner very definitely very firmly sits on this line. He is one of the children of systems, mentioned by Paulhan, who wonder.

\footnotetext{
52 See Stirner, Max, Das falsche Prinzip unserer Erziehung.

${ }^{53}$ Feyerabend, Paul, Against Method, p. 194
} 
Hitherto Stirner has been mainly read as an anarchic destructor of metaphysical concepts and the respective attitudes and derived from them. He has been also appreciated as a social philosopher, who promotes anarchy of the individual kind that favours self-fulfilment over taking on society-induced social roles. This essay attempts to show Stirner's theory in a different light. His theory can be judged as a warning against religiously believing in all sorts of all-encompassing hypotheses which predict how the world is and will be progressing, as well as a theory which emphasises a need for cool science in contrast to that kind of science which can become a religious force because it refuses its founding hypothesis to be upturned. To not upturn a hypothesis means "...fall prey to the principle of stability, the proper principle of religion, which concerns itself with ... creating "eternal truth""54.

Stirner had to halt in midair; he could not reasonably have gone on abandoning his newly found premises, but would hopefully have been the first one to have them discarded if having found out that mathematics as a self-relational system was construing rather than describing the world.

\section{Bibliography}

Carnap, Rudolf, "Die physikalische Sprache als Universalsprache der Wissenschaft", in: Wiener Kreis, Texte zur wissenschaftlichen Weltauffassung, Meiner Verlag. (Philosophische Bibliothek).

Dawkins, Richard, The God Delusion, London: Black Swan, 2007.

Engels, Friedrich; Marx, Karl, "Deutsche Ideologie, Das Leipziger Konzil III, Sankt Max”, In: Marx Engels Werke 3. Bd., Berlin: Akademie Verlag, 1969: 101-438.

Engels, Friedrich; Marx, Karl, German Ideology. http://www.marxists.org/ archive/marx/works/1845/german-ideology/index.htm

Feyerabend, Paul, Against Method, $8^{\text {th }}$ ed. London; New York: New Left Books, 2008.

Feyerabend, Paul, Killing Time, The Autobiography of, $5^{\text {th }}$ ed. Chicago; London: The University of Chicago Press, 1999.

Feyerabend, Paul, Realism, Rationalism \& Scientific Method. Philosophical Papers. Vol. I, London; New York, Cambridge University Press, 2003.

Hegel, Georg Friedrich Wilhelm, Wissenschaft der Logik, Erster Teil, Frankfurt am Main: Suhrkamp Verlag, 1986. (stw; 605).

Hume, David, A Treatise of Human Nature, Dover Pubns Inc., 2004. (Dover Philosophical Classics).

54 Stirner, Max, Der Einzige und sein Eigentum, S. 397; The Ego and His Own, p. 337, "dem Stabilitätsprinzip zu verfallen, dem eigentlichen Lebensprinzip der Religion, die sich's angelegen sein läßt ... “ewige Warheiten” zu kreieren”.. 
Kant, Immanuel, Kritik der reinen Vernunft, hrsg. v. Wilhelm Weischedel, 2. Aufl. Frankfurt am Main: Suhrkamp Verlag, 1976. (stw; 55).

Kuhn, Thomas S., The Structure of Scientific Revolutions, Chicago: University of Chicago Press, 1996.

Quine, Willard van Orman, Grundzüge der Logik, Frankfurt am Main: Suhrkamp Verlag, 1969.

Spinoza, Baruch, de, Die Ethik, Stuttgart: Philipp Reclam jun., 1990.

Stirner, Max, "Christenthum und Antichristenthum”, In: Kleine Schriften, hrsg. v. John Henry Mackay, Stuttgart - Bad Cannstatt: Frommann Holzboog, 1976. (Faksimile - Neudruck der 2. Auflage, Berlin 1914).

Stirner, Max, Der Einzige und sein Eigentum, Stuttgart: Philipp Reclam jun., (1846) 1972.

Stirner, Max, The Ego and His Own, The Case of the Individual Against Authority, hrsg. v. James J. Martin, Mineola, New York: Dover Publications, Inc. 2005 (1973).

Stirner, Max, "Über das unwahre Prinzip unserer Erziehung oder Der Humanismus und Realismus", In: Kleine Schriften, hrsg. v. John Henry Mackay, Stuttgart - Bad Cannstatt: Frommann - Holzboog, 1976. (Faksimile - Neudruck der 2. Auflage, Berlin 1914 ).

Trendelenburg, Friedrich Adolf, Logische Untersuchungen, 1. Aufl. Berlin: 1840.

Wendel, Hans Jürgen, “Das Abgrenzungsproblem”, In: Karl Popper, Logik der Forschung, hrsg. v. Herbert Keuth, Berlin: Akademie Verlag, 2007. (Klassiker Auslegen, hrsg. von Otfried Höffe): S. 41 - 66.

Zahar, Eli. G., "Falsifiability”. In: Karl Popper, Logik der Forschung, hrsg. v. Herbert Keuth, Berlin: Akademie Verlag, 2007. (Klassiker Auslegen, hrsg. von Otfried Höffe): S. $103-123$.

\section{RESUMO}

Apesar de se encontrarem historicamente separados por 150 anos, Stirner e Feyerabend parecem estar de acordo na revolta contra a explicação metodológica daquilo que não pode ser metodologicamente explicado. Stirner ensaiou uma explicação numa versão mais intuitiva. Feyerabend numa versão mais sofisticada. Para ambos os pensadores é obviamente importante sustentar um desacordo com a pressuposição de que o método é o único promotor vital do progresso científico. Eles dão igualmente voz à opinião de que, apesar de a ciência ela mesma produzir inconsistências tanto quanto resultados, os seus procedimentos seguem, não obstante, uma certa base racional. Mas codificar uma abordagem definitiva de olhar para as coisas transforma a ciência em religião e os cientistas em crentes. Como resultado, não são ganhos quaisquer novos conhecimentos. 


\begin{abstract}
Stirner and Feyerabend, despite being historically a hundred and fifty years apart, seem to have been of the same mind in revolting against the methodological explaining of what cannot methodologically be explained. Stirner attempted an explanation in a more intuitive version, Feyerabend in a more sophisticated one.

For both thinkers it is obviously important to sustain dissent with the assumption that method is the one and only vital promoter of scientific progress. They equally voice the opinion that, despite science itself producing inconsistencies as well as results, its proceedings nonetheless follow a certain rationale. But to codify a definite approach to phenomena or matter i.e. to establish a definite method for taking a look into things turns science into religion and scientists into believers. As a result no new insights are to be gained.
\end{abstract}

